\title{
EFFECT OF CULTIVARS, PLANT SPACING AND AL-GAMIX ON GROWTH AND GREEN YIELD OF BROAD BEAN (Vicia faba L.)
}

\author{
SAMIRA TAHIR ALI \\ Dept. of Horticulture, College of Agriculture, University of Duhok, Kurdistan Region -Iraq
}

(Received: January 13, 2019; Accepted for Publication: April 1, 2019)

\begin{abstract}
The experiment was amid to tested the effects of three Cultivars (Reina, Giza \& Local), two plant spacing $(15 \& 20 \mathrm{~cm})$ and Al-gamix at concentration $\left(0 \& 2 \mathrm{ml} . \mathrm{L}^{-1}\right)$ on growth, green yield and green seed yield of Broad bean (Vicia faba.). Results showed that the cultivars had affected on vegetative, green yield and seed yield characters; The Reina cultivar had significant increase in (No. of branches, Pod Yield g. plant ${ }^{-1}$, Total Yield ton. donum ${ }^{-1}$, No. of seed per pod, no. of seed. Plant ${ }^{-1}$, seed weight $\mathrm{g}$, seed yield.plant ${ }^{-1}$, Total seed yield ton. Donum ${ }^{-1}$ and weight of 100 seed $\mathbf{g}$ ). While Giza cultivar had a significant increase in (plant high, pod length $\mathrm{cm}$, pod weight $\mathrm{g}$ ). The local cultivar had a significant increase in (No. of pods per plant and No, of seed per plant)There were significant effect of plant spacing on vegetative and yield characters, $15 \mathrm{~cm}$ spacing increased (plant high $\mathrm{cm}$, No. of branches, pod weight $\mathrm{g}$, plant yield g. plant ${ }^{-1}$, total yield ton.donum-1). But $20 \mathrm{~cm}$ spacing significantly increased (No. of pods per plant, pod length $\mathrm{cm}$, No. of seed per pod, seed weight $\mathrm{g}$, weight of 100 seed $\mathrm{g}$ ), While treating of broad bean plant with $\mathrm{Al}$-gamix especially $\left(2 \mathrm{ml} . \mathrm{L}^{-1}\right)$ led to significant increases in all parameters like vegetative, green yield and green seed yield characters.
\end{abstract}

KEY WORD:- Faba bean, cultivars, plant spacing and Al-gamix

\section{INTRODUCTION}

F aba bean (Vicia faba L.) is the fourth most important pulse crop in the world with 4.316.371 tons produced (Anon., 2010). It contains a large amount of proteins, carbohydrates, B-group vitamins and minerals. The protein content (29.57- 31.83\%), carbohydrate (52.96-54.60\%), ash (3.37-3.47\%), fat (0.81-1.24\%) and fiber (10.88-11.96\%) of faba beans depends on the variety (Sarah et al., 2009). Faba beans play a key role in crop rotation due to their ability to fix nitrogen, and the beans are able to provide a significant level of nitrogen from the soil air using a symbiotic relationship with Rhizobium bacteria.

The main aim objective when growing the crop is to obtain the highest yield. However, there are several factors that affect the production such as sowing time, soil fertility, and varieties or genotypes. According to many studies carried out in faba bean, there are significant differences among varieties concerning yield and yield components (El-Masry, 2010; Osman et al., 2010;Darya, 2013 and Kubure et al., 2016). Another factor is seeding rate or planting density, which affect the growth, development and grain productivity per unit area in almost all agricultural crops, including faba bean, and is not stable for one variety due to different climate conditions. Low plant density may result in low yield; however, high plant density can cause lodging, less light penetration in the crop canopy, reduced photosynthetic efficiency and can reduce the yield drastically (Vassilev, 1998; Jettner et al., 1998a 1998b; Lemerle et al., 2004; Lemerle et al., 2006). Earlier studies have shown that yield and its components are affected by planting densities (Turk \& Tawaha, 2002; Bakry et al., 2011; Thalji, 2006 \& 2010; Khalil et al., 2011). Seaweed extracts are natural extracts of herb plants and sea algae, nowadays they are used widely in many areas as a source of growth regulators and that produce commercially. Seaweed extract (Ascophyllum nodosum) is also known by other names such as olive trees or sea grapes, and the company Golway alone collects about 34.000 tons per year of seaweeds. In England, these extracts were used in agriculture as fertilizers in restricted terms to improve soil conditions, nowadays, they are used world widely in various field of life's and are prepared as a 
powder or liquid (Potter, 2005). Zadape et al., (2008) recorded that spraying okra plants with liquid seaweed fertilizers with $0,2.5,5,7.5$ and $10 \%$ concentration, that concentration $2.5 \%$ significantly increased the fresh and dry weight of plant. Sabh g Shallan (2008) resulted in a study carried out on Faba bean plants that uses seaweed extract had significantly increased the number of leaves, plant length, leave area, dry weight of shoot and root growth and total chlorophyll content in leaves.

Allelah (2011) showed that spraying Melon plants with seaweed extract (Algamix and Alagren) that Algamix treated plant lead to significant increase in fruit weight, number of fruit per plant, total yield. Ismael (2012) revealed that spraying cucumber plants with seaweeds extract significantly enhanced fruit setting, increased number of fruit per plant, fruit weight, yield per plant, early yield, TSS and ascorbic acid percentage compared to control treatments.

Therefore, the present research was conducted to evaluate response of different local faba bean cultivars, planting densities and seaweed extract on the yield and yield components under the conditions of Duhok - kurdistan reign- Iraq.

\section{MATERIALS AND METHODS}

The experiment was conducted in the Vegetable Research Farm, Horticultural Department, College of Agriculture, University of Duhok, Kurdistan region/Iraq, during the growing season of 2014-2015. To study the effect of cultivars, plant spacing and Al-gamix on growth and green yield of broad bean cultivars. The cultivars were planted on $14^{\text {th }}$ November 2015 in the farm. Seed planting was achieved on both sides of ridges at $25 \mathrm{~cm}$ between hills and $75 \mathrm{~cm}$ between ridges. urea fertilizer was added $(46 \% \mathrm{~N})$ at a rate of $30 \mathrm{~kg}$. Dunm ${ }^{-1}$ in a ditch way after a month of cultivation. All agricultural operations were carried out in the production of this crop from irrigation, weeding. Irrigation was carried out according to plant needs.

The experiment was conducted in split split plot design, the three cultivars (Reina, Giza and locale) in main plot and the two spacing (15 and $25 \mathrm{~cm})$ in sub plots and Al-gamix $\left(0,2 \mathrm{~m} \cdot \mathrm{L}^{-1}\right)$ in sub sub plot and was arranged in a randomized complete block design (RCBD). Each treatment included eight plants with three replication. Spraying plants with Al-gamix was done three times, the first one added 45days after planting and the other one at ten day between them. Data were analyzed by using the (SAS program, 2007). Means values were compared using Duncan's multiple range tests at $0.05 \%$ level (AL-Rawi and Khalaf Alah, 2000). Data were recorded for plant high, No. of branches/plant, No. of pods per plant, pod length $\mathrm{cm}$, pods weight $\mathrm{g}$, pod yield g. plant ${ }^{-1}$, total yield ton. donum ${ }^{-1}$, No. of seeds pod, No. of green seeds plant ${ }^{-1}$, fresh seed weight $(\mathrm{mg})$, weight of 100 seed $(\mathrm{g})$, green seed yield plant $(\mathrm{g})$, total green seed yield ton. donum ${ }^{-1}$.

\section{RESULTS}

1-Vegetative Growth Characters:-

\section{Plant High.}

Data in table (1) shows that significant differences occurred between cultivars, Giza cultivar superior to other cultivars which gave $85.13 \mathrm{~cm}$ high. Also significant differences had been obtained between two spacing on plant hight, the $15 \mathrm{~cm}$ gave the longer $(83.97 \mathrm{~cm})$ as compared to $20 \mathrm{~cm}(81.82 \mathrm{~cm})$. Significant differences was obtained on plant high when sprayed with Algamix the highest plant high $(85.53 \mathrm{~cm})$ in $2 \mathrm{~g} . \mathrm{L}^{-1}$.

The interaction between cultivars and spacing was significant in its effect, Giza planted in $15 \mathrm{~cm}$ spacing gave the higher value $(87.13 \mathrm{~cm})$ compared to other interaction. Significant differences found between cultivars and Al-gamix the highest value obtained between Reina and Algamix reached $(90.98 \mathrm{~cm})$, while the interaction between spacing and Al-gamix also significant differences occurred the interaction between spacing and $\mathrm{Al}$-gamix $\left(2 \mathrm{~m} . \mathrm{L}^{-1}\right)$ reached $(87.86 \mathrm{~cm})$. The triple interaction among three factors revealed that significant differences occurred and the highest value was $(92.57 \mathrm{~cm})$ between Reina, 20 $\mathrm{cm}$ and $2 \mathrm{~m}$. $\mathrm{L}^{-1}$, while the lowest value $(72.10 \mathrm{~cm})$ between Reina, $20 \mathrm{~cm}$ spacing and control treatment. 
Table (1): Effect of cultivars, plant spacing, Al-gamix and their interaction on length $(\mathrm{cm})$ of Broad bean.

\begin{tabular}{|c|c|c|c|c|c|}
\hline \multirow[t]{3}{*}{ var. } & \multirow{3}{*}{ 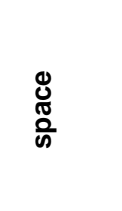 } & \multicolumn{2}{|c|}{ Al-gamix } & var & \multirow[t]{3}{*}{ Var. } \\
\hline & & \multirow[t]{2}{*}{ Control } & \multirow[t]{2}{*}{$2 m \cdot L^{-1}$} & * & \\
\hline & & & & spacing & \\
\hline \multirow[t]{2}{*}{ Reina } & 15 & $76.87 \mathrm{~d}$ & $89.40 \mathrm{a}$ & $83.13 b$ & $82.73 b$ \\
\hline & 20 & $72.10 \mathrm{e}$ & $92.57 a$ & $82.33 b$ & \\
\hline \multirow[t]{2}{*}{ Giza } & 15 & $83.47 \mathrm{bc}$ & $90.80 a$ & $87.13 a$ & $85.13 a$ \\
\hline & 20 & 87.77ab & $78.47 \mathrm{~cd}$ & $83.12 b$ & \\
\hline \multirow[t]{2}{*}{ Local } & 15 & $79.90 \mathrm{~cd}$ & $83.37 \mathrm{bc}$ & $81.63 b$ & $80.82 b$ \\
\hline & 20 & $81.40 \mathrm{~cd}$ & $78.60 \mathrm{~cd}$ & $80.00 \mathrm{~b}$ & \\
\hline \multicolumn{2}{|l|}{ Al-gamix } & $80.25 b$ & $85.53 a$ & & \\
\hline var. & Reina & $74.48 d$ & $90.98 a$ & spacing & \\
\hline * & Giza & $85.62 b$ & $84.63 b$ & & \\
\hline conc. & Local & $80.65 c$ & $80.98 c$ & & \\
\hline spacing. & control & $80.08 c$ & $87.86 a$ & $83.97 a$ & \\
\hline *Al-gamix & $2 m \cdot L^{-1}$ & $80.42 c$ & $83.21 b$ & $81.82 b$ & \\
\hline
\end{tabular}

Means within a column, row and there interactions followed with the same letters are not significantly different from each others according to Duncan multiple ranges test at $5 \%$ level.

\section{Number of Branch's per plants.}

Table (2) revealed that significant differences occurred between cultivars, Reina cultivar gave the higher number of branch (5.12 branch/plant) compared to other cultivars. Significant differences had been in spacing the highest value (5.27 branch/plant) in $15 \mathrm{~cm}$ spacing. Also $2 \mathrm{ml}^{-\mathrm{L}^{-1}}$ superior to control treatment which gave (4.95 branch/plant). The interaction between cultivars and spacing had significantly effected the Giza cultivars planted in $15 \mathrm{~cm}$ spacing gave the highest value (6.03 branch/plant), also the interaction between cultivars and Al-gamix had significant effect on the highest value (5.53 branch/plant) when spray Reina cultivars with $2 \mathrm{ml} . \mathrm{L}^{-1}$. The highest no. of branches (5.68 branch/plant) was observed between spacing $15 \mathrm{~cm}$ and $2 \mathrm{ml} . \mathrm{L}^{-1} \mathrm{Al}-$ gamix. The triple interaction between three factors had significant effect, the highest branches per plant (6.57 branch/plant) was observed among Reina, $15 \mathrm{~cm}$ spacing and $2 \mathrm{ml} . \mathrm{L}^{-1}$ Al-gamix as compared to other interaction and the lowest value (3.30 branch/plant) among Giza cultivar, $20 \mathrm{~cm}$ and control treatment.

Table (2): Effect of Cultivars, plant spacing, Al-gamix and their interaction on number of branch's per plant of Broad bean.

\begin{tabular}{|c|c|c|c|c|c|}
\hline \multirow[t]{3}{*}{ var. } & \multirow{3}{*}{ 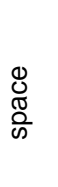 } & \multicolumn{2}{|c|}{ Al-gamix } & \multirow{2}{*}{$\frac{\text { var }}{\text { * }}$} & \multirow[t]{3}{*}{ Var. } \\
\hline & & control & $2 \mathrm{ml} \mathrm{L}^{-1}$ & & \\
\hline & & & & spacing & \\
\hline Reina & 15 & $4.60 \mathrm{de}$ & $6.57 \mathrm{a}$ & $5.58 \mathrm{~b}$ & $5.12 a$ \\
\hline
\end{tabular}




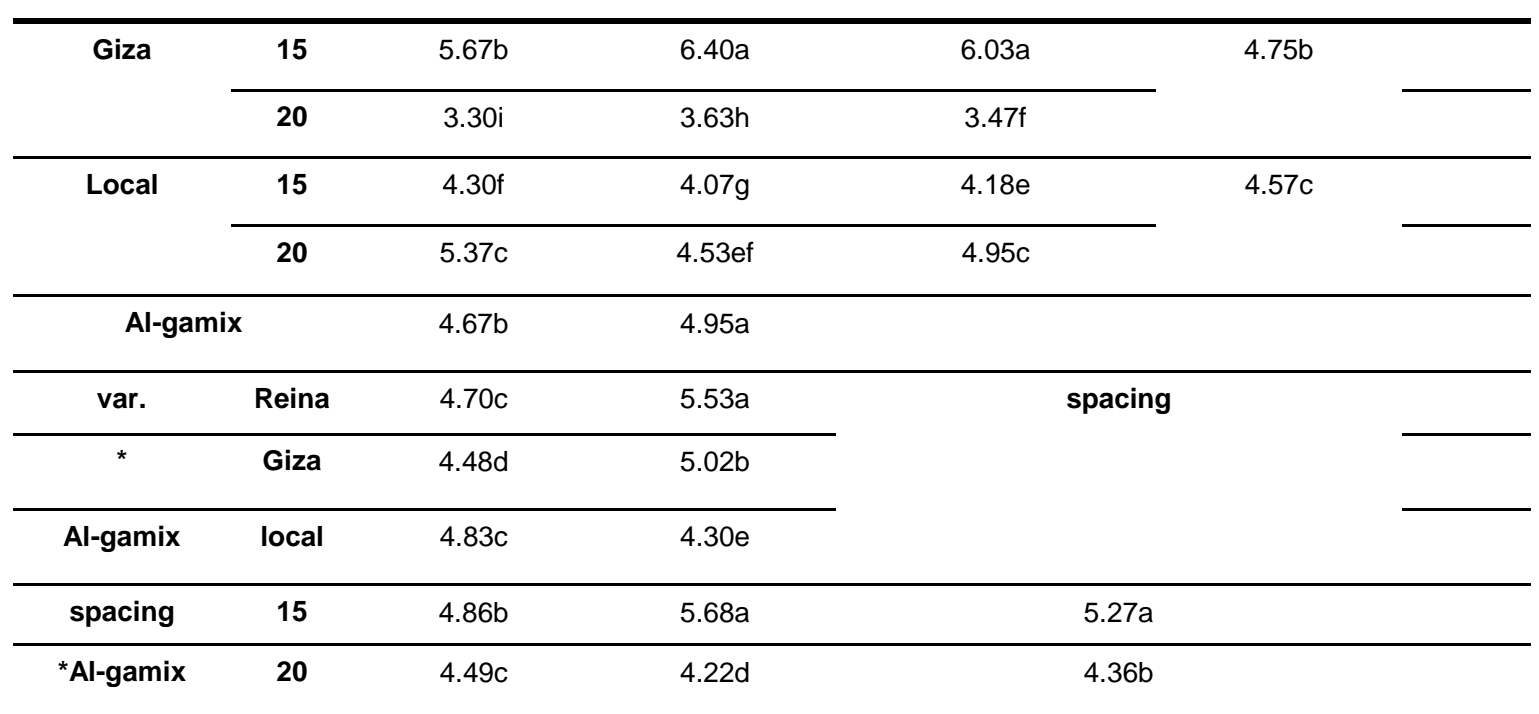

Means within a column, row and there interactions followed with the same letters are not significantly different from each others according to Duncan multiple ranges test at $5 \%$ level.

\section{2-Green Yield Characters:-}

Number of pods per plant.

Table (3) illustrated that significant effect of cultivars on No. of pods per plant the highest value (22.97 pod. plant ${ }^{-1}$ ) occurred from Local cultivar, there were significant effect of spacing and $\mathrm{Al}$-gamix, $20 \mathrm{~cm}$ spacing and $2 \mathrm{ml} . \mathrm{L}^{-1}$ gave the highest value (22.12 and 22.72 pod. plant $^{-1}$ ) respectively. The dual interaction had significant effect and gave the highest No. of pods (24.73 pod.plant ${ }^{-1}$ ) in interaction between Reina cultivar and $15 \mathrm{~cm}$ spacing compared to other interaction.
Also the highest No. (24.58pod.plant $\left.{ }^{-1}\right)$ between Reina and $2 \mathrm{ml} . \mathrm{L}^{-1}$ compared to other interaction treatments. There were significant difference between spacing and Al-gamix and the highest value was $\left(23.74\right.$ pod.plant $\left.{ }^{-1}\right)$ between $20 \mathrm{~cm}$ spacing and $2 \mathrm{ml} . \mathrm{L}^{-1}$ as compared to other interaction.

The interaction among three treatments had significant effect the highest value (27.73

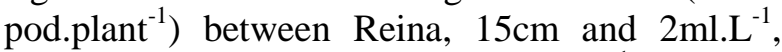
while the lowest value (16.67pod.plant ${ }^{-1}$ ) between Giza cultivar, $15 \mathrm{~cm}$ and $2 \mathrm{ml} . \mathrm{L}^{-1}$ Al-gamix.

Table (3): Effect of, cultivars, plant spacing, Al-gamix and their interaction on No. of pods per plant (pod.plant ${ }^{-1}$ ) of Broad bean.

\begin{tabular}{|c|c|c|c|c|c|}
\hline \multirow[t]{3}{*}{ var. } & \multirow{3}{*}{$\begin{array}{l}0 \\
\mathbb{\widetilde { J }} \\
\text { के }\end{array}$} & \multicolumn{2}{|c|}{ Al-gamix } & \multirow{2}{*}{$\frac{\text { var }}{\text { * }}$} & \multirow[t]{3}{*}{ Var. } \\
\hline & & \multirow[t]{2}{*}{ Control } & \multirow[t]{2}{*}{$2 \mathrm{ml.} .^{-1}$} & & \\
\hline & & & & spacing & \\
\hline \multirow[t]{2}{*}{ Reina } & 15 & $21.73 d$ & $27.73 a$ & $24.73 a$ & \multirow[t]{2}{*}{$22.45 b$} \\
\hline & 20 & $18.90 f$ & 21.43de & $20.17 c$ & \\
\hline \multirow[t]{2}{*}{ Giza } & 15 & $18.97 f$ & $16.67 \mathrm{~h}$ & $17.82 d$ & \multirow[t]{2}{*}{$19.78 c$} \\
\hline & 20 & $17.80 \mathrm{~g}$ & $25.67 b$ & $21.73 b$ & \\
\hline \multirow[t]{2}{*}{ Local } & 15 & $22.23 d$ & $20.70 \mathrm{e}$ & $21.47 b$ & \multirow[t]{2}{*}{$22.97 a$} \\
\hline & 20 & $24.80 \mathrm{bc}$ & $24.13 c$ & $24.47 a$ & \\
\hline \multicolumn{2}{|c|}{ Al-gamix } & $20.74 b$ & $22.72 a$ & & \\
\hline var. & Reina & $20.32 \mathrm{e}$ & $24.58 a$ & spacing & \\
\hline
\end{tabular}




\begin{tabular}{ccccc}
\hline$*$ & Giza & $18.38 \mathrm{f}$ & $21.17 \mathrm{~d}$ & \\
\hline Al-gamix & Local & $23.52 \mathrm{~b}$ & $22.42 \mathrm{c}$ & \\
\hline spacing & B1 & $20.98 \mathrm{c}$ & $21.70 \mathrm{~b}$ & $21.34 \mathrm{~b}$ \\
\hline${ }^{*}$ Al-gamix & B2 & $20.50 \mathrm{c}$ & $23.74 \mathrm{a}$ & $22.12 \mathrm{a}$ \\
\hline
\end{tabular}

Means within a column, row and there interactions followed with the same letters are not significantly different from each others according to Duncan multiple ranges test at 5\% level.

\section{Pod Length (cm).}

Data in table (4) shows that significant effect between cultivars on pod length and the Giza and Local cultivars superiority over the Reina cultivars reached $(14.28 \& 14.23 \mathrm{~cm})$ respectively. There were significant differences of plant spacing on pod length the highest value $(14.14 \mathrm{~cm})$ in $20 \mathrm{~cm}$ spacing. The treated plants with Al-gamix had significant effectson the highest pods length $(14.55 \mathrm{~cm})$ in $2 \mathrm{ml} . \mathrm{L}^{-1}$ concentration.

The interaction between cultivars and spacing significantly affected on pod length, the highest value $(14.78 \mathrm{~cm})$ in the interaction between Giza and $15 \mathrm{~cm}$ spacing, and the highest pod length $(15.10 \mathrm{~cm})$ obtained between Giza and $2 \mathrm{ml} . \mathrm{L}^{-1}$.The interaction between spacing and Algamix had significant effect, the highest value $(14.86 \mathrm{~cm})$ between $20 \mathrm{~cm}$ spacing and $2 \mathrm{ml} . \mathrm{L}^{-1} \mathrm{Al}$-gamix was obtained. The interaction among three factors had significant effect and the interaction among Giza, $15 \mathrm{~cm}$ and $2 \mathrm{ml} . \mathrm{L}^{-1}$ gave highest value $(15.70 \mathrm{~cm})$ compared to other interactions.

Table (4): Effect of cultivars, plant spacing,Algamix and their interaction on pod length (cm) of Broad bean.

\begin{tabular}{|c|c|c|c|c|c|}
\hline \multirow[t]{3}{*}{ var. } & \multirow{3}{*}{$\begin{array}{l} \pm \\
\mathbb{\varpi} \\
\frac{0}{\infty}\end{array}$} & \multicolumn{2}{|c|}{ Al-gamix } & var & \multirow[t]{3}{*}{ Var. } \\
\hline & & \multirow[t]{2}{*}{ control } & \multirow[t]{2}{*}{$2 \mathrm{ml} \cdot \mathrm{L}^{-1}$} & * & \\
\hline & & & & spacing & \\
\hline \multirow[t]{2}{*}{ Reina } & 15 & $10.67 \mathrm{~g}$ & $12.43 f$ & $11.55 d$ & $12.94 b$ \\
\hline & 20 & $13.53 d$ & $15.13 b$ & $14.33 b$ & \\
\hline \multirow[t]{2}{*}{ Giza } & 15 & $13.87 d$ & $15.70 \mathrm{a}$ & $14.78 \mathrm{a}$ & $14.28 a$ \\
\hline & 20 & $13.07 e$ & $14.50 c$ & $13.78 \mathrm{c}$ & \\
\hline \multirow[t]{2}{*}{ Local } & 15 & $13.70 d$ & $14.60 c$ & $14.15 b$ & $14.23 a$ \\
\hline & 20 & $13.70 d$ & $14.93 \mathrm{bc}$ & $14.32 b$ & \\
\hline \multicolumn{2}{|l|}{ Conc. } & $13.09 b$ & $14.55 a$ & & \\
\hline var. & Reina & $12.10 \mathrm{e}$ & $13.78 \mathrm{c}$ & Spacing & \\
\hline * & Giza & $13.47 d$ & $15.10 a$ & & \\
\hline Al-gamix & Local & $13.70 \mathrm{~cd}$ & $14.77 \mathrm{~b}$ & & \\
\hline spacing & 15 & $12.74 d$ & $14.24 b$ & $13.49 b$ & \\
\hline *Al-gamix & 20 & $13.43 c$ & $14.86 \mathrm{a}$ & $14.14 a$ & \\
\hline
\end{tabular}

Means within a column, row and there interactions followed with the same letters are not significantly different from each others according to Duncan multiple ranges test at 5\% level.

\section{Pods Weight (g).}

Table (5) illustrate that there were significant differences between cultivars on pod weigh of broad bean, Giza cultivar superior to other two cultivars which gave $(11.97 \mathrm{~g})$. The plant spacing significantly increased pod weight the $15 \mathrm{~cm}$ 
superior over the $20 \mathrm{~cm}$ (11.31 and $10,82 \mathrm{~g})$ respectively. The treatment with Al-gamix also had significant effect and the highest one $(11.14 \mathrm{~g})$ in $2 \mathrm{ml} . \mathrm{L}^{-1}$ concentration compared to control. As the effect of dual interaction significantly affected on pod weight, the interaction between Giza cultivars and $15 \mathrm{~cm}$ space superior over other interaction which gave highest value $(12.90 \mathrm{~g})$ while the lowest value $(9.65 \mathrm{~g})$ obtained from the interaction between local cultivar and $20 \mathrm{~cm}$ space. The other interactions between cultivars and Algamix had a significant effect on pod weight the highest value (12.27g) was observed between Giza cultivar and control treatment. In the interaction between spacing and Al-gamix also significant effect and the highest weight $(11.64 \mathrm{~g})$ it was between spacing and $2 \mathrm{ml} . \mathrm{L}^{-1}$, but the lowest value $(10.65 \mathrm{~g})$ between $20 \mathrm{~cm}$ space and $2 \mathrm{ml}^{-\mathrm{L}^{-1}}$ treatment. The interaction among three factors significantly affected on pod weight the highest pod weight $(14.22 \mathrm{~g})$ was observed among Giza cultivar, $15 \mathrm{~cm}$ space and $2 \mathrm{ml} . \mathrm{L}^{-1}$ treatment, while the lowest one $(9.38 \mathrm{~g})$ was noticed among Local cultivar, $20 \mathrm{~cm}$ space and control treatment.

Table (5): Effect of cultivars, plant spacing, Al-gamix and their interaction on pod weight (g) of Broad bean.

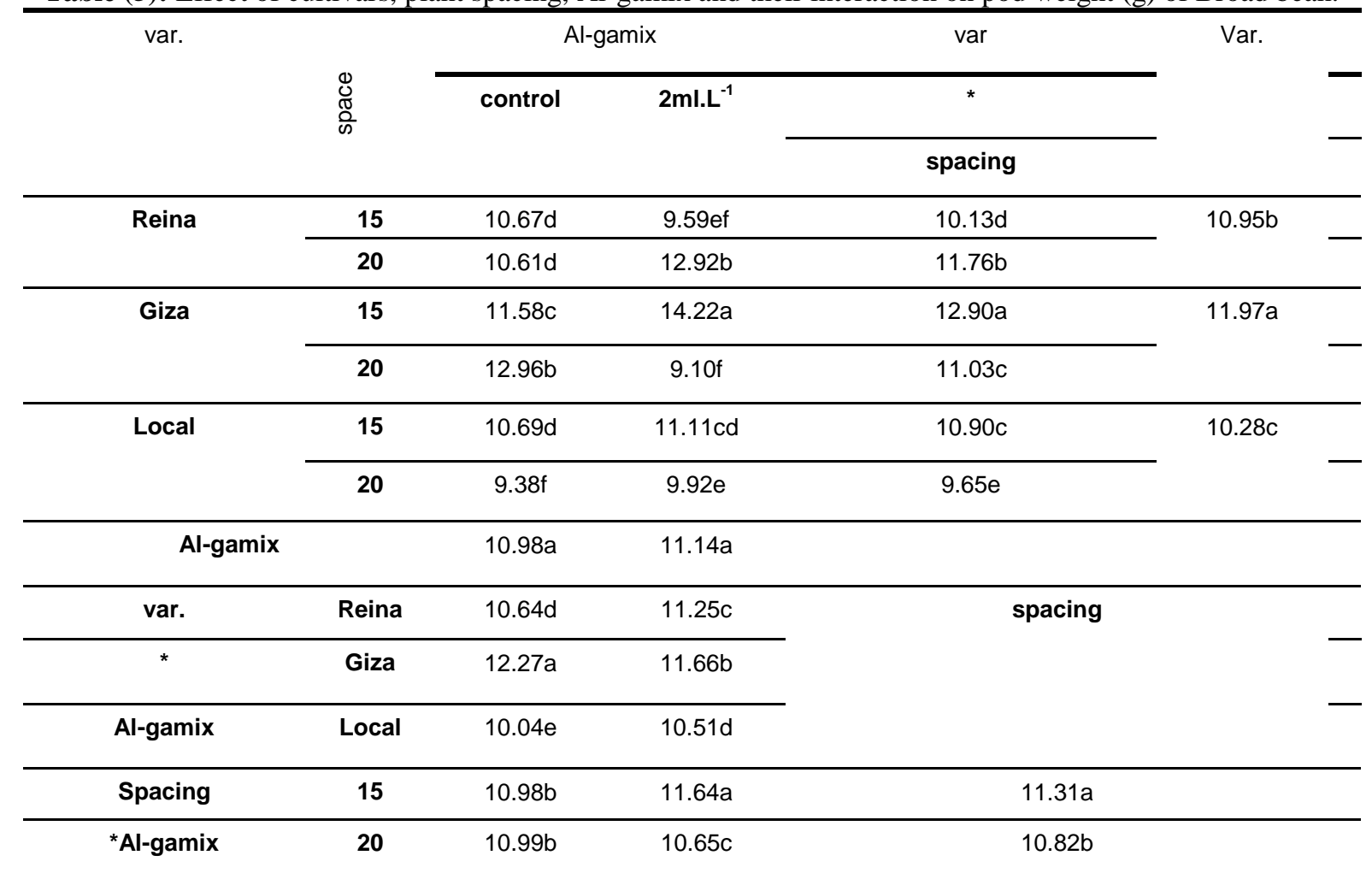

Means within a column, row and there interactions followed with the same letters are not significantly different from each others according to Duncan multiple ranges test at $5 \%$ level.

\section{Pod Yield ( g. plant ${ }^{-1}$ ).}

Data in table (6) shows that the Reina cultivar superior over the two other cultivar on pod yield per plant (243.43g.plant ${ }^{-1}$ ). As the effect of spacing had a significant effect on plant yield $15 \mathrm{~cm}$ gave the higher yield (236.83g.plant ${ }^{-1}$ ). There were significant effect of Al-gamix on the pod yield per plant and the highest value (247.06 g.plant ${ }^{-1}$ ) compared to control treatment. The interaction between cultivars and spacing had a significant effect pod yield, the Reina cultivar planted in $15 \mathrm{~cm}$ spacing gave the higher yield (248.42g.plant ${ }^{-1}$ ) as compared to other interaction. The interaction between cultivars and Al-gamix had significant effect and the highest value $\left(271.30\right.$ g.plant $\left.{ }^{-1}\right)$ was noticed in the interaction between Reina and $2 \mathrm{ml} \cdot \mathrm{L}^{-1}$. The interaction between spacing and Al-gamix had significant effect the highest value

The interaction among three factors significantly increased pod yield of broad bean plants, the highest pod yield (276.77 g. plant $\left.{ }^{-1}\right)$ among Reina cultivar, $20 \mathrm{~cm}$ spacing and $2 \mathrm{ml} . \mathrm{L}^{-}$ ${ }^{1} \mathrm{Al}$-gamix compared to the other interaction and the lowest value had $\left(200.50 \mathrm{~g}\right.$. plant $\left.^{-1}\right)$ between Reina, $20 \mathrm{~cm}$ spacing and control treatments. 
Table (6): Effect of cultivars, plant spacing, Al-gamix and their interaction on Pod Yield ( g. plant $^{-1}$ ) of Broad bean.

\begin{tabular}{|c|c|c|c|c|c|}
\hline \multirow[t]{3}{*}{ var. } & \multirow{3}{*}{$\begin{array}{l}\stackrel{0}{0} \\
\text { ల్ల } \\
\text { क }\end{array}$} & \multicolumn{2}{|c|}{ Al-gamix } & var & \multirow[t]{3}{*}{ Var. } \\
\hline & & \multirow[t]{2}{*}{ Control } & \multirow[t]{2}{*}{$2 \mathrm{ml} \cdot \mathrm{L}^{-1}$} & * & \\
\hline & & & & spacing & \\
\hline \multirow[t]{2}{*}{ Reina } & 15 & $231.00 \mathrm{fg}$ & $265.83 b$ & $248.42 a$ & $243.53 a$ \\
\hline & 20 & $200.50 \mathrm{i}$ & $276.77 a$ & $238.63 b$ & \\
\hline \multirow[t]{2}{*}{ Giza } & 15 & 219.67h & $236.93 d$ & $228.30 f$ & $230.24 c$ \\
\hline & 20 & $230.70 \mathrm{~g}$ & $233.67 e$ & $232.18 \mathrm{e}$ & \\
\hline \multirow[t]{2}{*}{ Local } & 15 & $237.70 \mathrm{~cd}$ & $229.83 \mathrm{~g}$ & $233.77 d$ & $234.89 b$ \\
\hline & 20 & 232.73ef & $239.30 c$ & $236.02 c$ & \\
\hline \multicolumn{2}{|l|}{ Algamix } & $225.38 b$ & $247.06 a$ & & \\
\hline var. & Reina & $215.75 d$ & $271.30 a$ & & \\
\hline * & Giza & $225.18 \mathrm{c}$ & $235.30 b$ & & \\
\hline Al-gamix & Local & $235.22 b$ & $234.57 b$ & & \\
\hline Spacing & 15 & $229.46 c$ & $244.20 b$ & & \\
\hline${ }^{\star} A l$-gamix & 20 & $221.31 d$ & $249.91 \mathrm{a}$ & & \\
\hline
\end{tabular}

Means within a column, row and there interactions followed with the same letters are not significantly different from each others according to Duncan multiple ranges test at 5\% level.

\section{Total Yield (ton. donum ${ }^{-1}$ ).}

Table (7) shows that the Reina cultivar was superior over the other cultivar on total yield per plant (1.53 ton.donum $\left.{ }^{-1}\right)$. As the effect of two spacing had a significant effect on total yield, $15 \mathrm{~cm}$ spacing gave the higher total yield (1.49 ton.donum $\left.{ }^{-1}\right)$. There were significant effect of Algamix on the total yield per donum and the highest value $\left(1.55\right.$ ton.donum $\left.{ }^{-1}\right)$ in the $2 \mathrm{ml} \mathrm{L}^{-1}$ concentration compared to others. The interaction between cultivars and spacing was a significant effect on total yield, the interaction between Reina cultivars and $15 \mathrm{~cm}$ gave the highest value $(1.56$ ton.donum ${ }^{-1}$ ) as compared to other interaction. Also the interaction between Reina cultivar and
$2 \mathrm{ml} . \mathrm{L}^{-1}$ gave the higher total yield (1.71ton.donum $\left.{ }^{-1}\right)$ compared to other interaction. The interaction between spacing and Al-gamix was significant effect the highest value (1.57 ton.donum ${ }^{-1}$ ) between $20 \mathrm{~cm}$ spacing and $2 \mathrm{ml} . \mathrm{L}^{-}$ ${ }^{1} \mathrm{Al}$-gamix.

The interaction among three factors significantly increased total yield of broad bean plants, the highest total yield (1.74 ton.donum $\left.{ }^{-1}\right)$ was observed among Reina cultivar, $20 \mathrm{~cm}$ spacing and $2 \mathrm{ml} . \mathrm{L}^{-1} \mathrm{Al}$-gamix compared to the other interaction and the lowest value had (1.26 ton.donum ${ }^{-1}$ ) between Reina cultivar, $20 \mathrm{~cm}$ spacing and control treatments. 
Table (7): Effect of cultivars, plant spacing, Al-gamix and their interaction on Total Yield (kg.m ${ }^{-2}$ ) of Broad bean plant.

\begin{tabular}{|c|c|c|c|c|c|}
\hline \multirow[t]{3}{*}{ var. } & \multirow{3}{*}{ 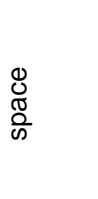 } & \multicolumn{2}{|c|}{ Al-gamix } & var & \multirow[t]{3}{*}{ Var. } \\
\hline & & control & $2 \mathrm{ml} \cdot \mathrm{L}^{-1}$ & * & \\
\hline & & & \multicolumn{2}{|r|}{ spacing } & \\
\hline \multirow[t]{2}{*}{ Reina } & 15 & $1.45 \mathrm{fg}$ & $1.67 b$ & $1.56 \mathrm{a}$ & $1.53 a$ \\
\hline & 20 & $1.26 \mathrm{i}$ & $1.74 a$ & $1.50 \mathrm{~b}$ & \\
\hline \multirow[t]{2}{*}{ Giza } & 15 & $1.38 \mathrm{~h}$ & $1.49 d$ & $1.44 f$ & $1.45 c$ \\
\hline & 20 & $1.45 \mathrm{~g}$ & $1.47 \mathrm{e}$ & $1.46 \mathrm{e}$ & \\
\hline \multirow[t]{2}{*}{ Local } & 15 & $1.49 \mathrm{~cd}$ & $1.45 \mathrm{~g}$ & $1.47 d$ & $1.48 b$ \\
\hline & 20 & $1.46 \mathrm{ef}$ & $1.50 c$ & $1.48 c$ & \\
\hline \multicolumn{2}{|l|}{ Algamix } & $1.42 b$ & $1.55 a$ & & \\
\hline var. & Reina & $1.36 \mathrm{~d}$ & $1.71 \mathrm{a}$ & Spacing & \\
\hline * & Giza & $1.42 \mathrm{c}$ & $1.48 b$ & & \\
\hline Al-gamix & Local & $1.48 b$ & $1.47 \mathrm{~b}$ & & \\
\hline spacing & 15 & $1.44 \mathrm{c}$ & $1.54 b$ & $1.49 a$ & \\
\hline${ }^{*} \mathrm{Al}$-gamix & 20 & $1.39 d$ & $1.57 a$ & $1.48 b$ & \\
\hline
\end{tabular}

Means within a column, row and there interactions followed with the same letters are not significantly different from each others according to Duncan multiple ranges test at $5 \%$ level.

\section{3-Green Seed Yield Characters: Number of Seeds per Pod.}

The data in table (8) illustrated that significant effect of cultivars on No. of seeds per pod and the Reina cultivar overcome to other cultivar (5.01 seed. $\left.\operatorname{pod}^{-1}\right)$, no significant effect of spacing occurred. But significant differences occurred when sprayed with Al-gamix resulting the highest value (5.13 seed.pod $\left.{ }^{-1}\right)$ compared to control (4.27 seed.pod $\left.{ }^{-1}\right)$. The interaction between cultivars and spacing had significant effect and the highest No. of seeds (5.82 seed.pod $\left.{ }^{-1}\right)$ in interaction between Reina and $20 \mathrm{~cm}$ spacing. The interaction between cultivars and Algamix also significantly affected on the No. of seeds and highest value (5.53 and5.57.seed.pod ${ }^{-1}$ ) was occurred between Reina and Giza cultivars and $2 \mathrm{ml} . \mathrm{L}^{-1}$ respectively. There were significant effect between spacing and Algamix and the highest value (5.21and 5.04seed. pod $^{-1}$ ) between $2 \mathrm{ml} . \mathrm{L}^{-1}$ Al-gamix and the two spacing respectively.

The three interaction among treatments had significant effect the highest value (6.27 and 6.50 seed.pod ${ }^{-1}$ ) among Reina and Giza cultivars, 20 and $15 \mathrm{~cm}$ spacing and $2 \mathrm{ml} . \mathrm{L}^{-1}$ respectively compared to other interaction and the lowest value (3.60seed.pod ${ }^{-1}$ ) between Reina, $15 \mathrm{~cm}$ spacing and control treatment. 
Table (8): Effect of cultivars, plant spacing, Al-gamix and their interaction on No. of seed per pod of Broad bean.

\begin{tabular}{|c|c|c|c|c|c|}
\hline \multirow[t]{3}{*}{ var. } & \multirow{3}{*}{$\begin{array}{l}\mathscr{\mathscr { J }} \\
\tilde{\tilde{n}}\end{array}$} & \multicolumn{2}{|c|}{ Algamix } & \multirow{2}{*}{$\begin{array}{c}\text { var } \\
*\end{array}$} & \multirow[t]{3}{*}{ Var. } \\
\hline & & \multirow[t]{2}{*}{ Control } & \multirow[t]{2}{*}{$2 \mathrm{ml} . \mathrm{L}^{-1}$} & & \\
\hline & & & & spacing & \\
\hline \multirow[t]{2}{*}{ Reina } & 15 & $3.60 \mathrm{f}$ & $4.80 \mathrm{c}$ & $4.20 \mathrm{~cd}$ & $5.01 \mathrm{a}$ \\
\hline & 20 & $5.37 \mathrm{~b}$ & $6.27 \mathrm{a}$ & $5.82 \mathrm{a}$ & \\
\hline \multirow[t]{2}{*}{ Giza } & 15 & $4.50 \mathrm{~cd}$ & $6.50 \mathrm{a}$ & $5.50 \mathrm{~b}$ & $4.98 \mathrm{a}$ \\
\hline & 20 & $4.27 \mathrm{de}$ & $4.63 \mathrm{~cd}$ & $4.45 \mathrm{c}$ & \\
\hline \multirow[t]{2}{*}{ Local } & 15 & $3.93 \mathrm{ef}$ & $4.33 \mathrm{cde}$ & $4.13 \mathrm{~cd}$ & $4.12 \mathrm{~b}$ \\
\hline & 20 & $3.97 \mathrm{ef}$ & $4.23 \mathrm{de}$ & $4.10 \mathrm{~d}$ & \\
\hline \multicolumn{2}{|l|}{ Al-gamix } & $4.27 \mathrm{~b}$ & $5.13 a$ & & \\
\hline var. & Reina & $4.48 \mathrm{~b}$ & $5.53 \mathrm{a}$ & spacing & \\
\hline$*$ & Giza & $4.38 \mathrm{~b}$ & $5.57 \mathrm{a}$ & & \\
\hline Al-gamix & Local & $3.95 \mathrm{c}$ & $4.28 \mathrm{~b}$ & & \\
\hline Spacing & 15 & $4.01 \mathrm{c}$ & $5.21 \mathrm{a}$ & $4.61 \mathrm{a}$ & \\
\hline *Al-gamix & 20 & $4.53 \mathrm{~b}$ & $5.04 \mathrm{a}$ & $4.79 \mathrm{a}$ & \\
\hline
\end{tabular}

Means within a column, row and there interactions followed with the same letters are not significantly different from each others according to Duncan multiple ranges test at $5 \%$ level.

\section{Number of Seeds per Plant.}

The table (9) shows that significant effect of cultivars on No. of seeds per plant, the Reina cultivar overcome to other two cultivars which gave (111.67 seed.plant $\left.{ }^{-1}\right)$, Also significant effect of spacing occurred and $20 \mathrm{~cm}$ gave highest value (105.18 seed.plant ${ }^{-1}$ ) compared to $15 \mathrm{~cm}$ spacing (96.98 seed.plant ${ }^{-1}$ ). The effect of Al-gamix significantly increased the No. of seeds and $2 \mathrm{ml} . \mathrm{L}^{-}$ ${ }^{1}$ gave the highest value (114.42 seed.plant ${ }^{-1}$ ) compared to control treatment (87.74 seed.plant ${ }^{-1}$ ). The interaction between cultivars and spacing had significant effect and the highest No. of seeds (117.85 seed.plant $\left.{ }^{-1}\right)$ in interaction between Reina and $20 \mathrm{~cm}$ spacing. The interaction between cultivars and Al-gamix also significantly affected on the No. of seeds and highest value (133.69seed.plant $\left.{ }^{-1}\right)$ was occurred between Reina and $2 \mathrm{ml} . \mathrm{L}^{-1}$ treatments, and there were briefly significant between spacing and Al-gamix and the highest value (118.44 seed. plant $\left.{ }^{-1}\right)$ occurred between $20 \mathrm{~cm}$ spacing and $2 \mathrm{ml} . \mathrm{L}^{-1}$ conc. Al-gamix as compared to other interaction. The three interaction among treatments had a significant effect, the highest value (133.12 and 134.26 seed.plant ${ }^{-1}$ ) among Reina cultivar, two spacing and $2 \mathrm{ml} . \mathrm{L}^{-1}$ respectively compared to other interaction and the lowest value (75.97 seed.plant $^{-}$ $\left.{ }^{1}\right)$ among Giza cultivar, $20 \mathrm{~cm}$ spacing and control treatment. 
Table (9): Effect of cultivars, plant spacing, Al-gamix and their interaction on No. of seeds per plant (seed.plant ${ }^{-1}$ ) of Broad bean.

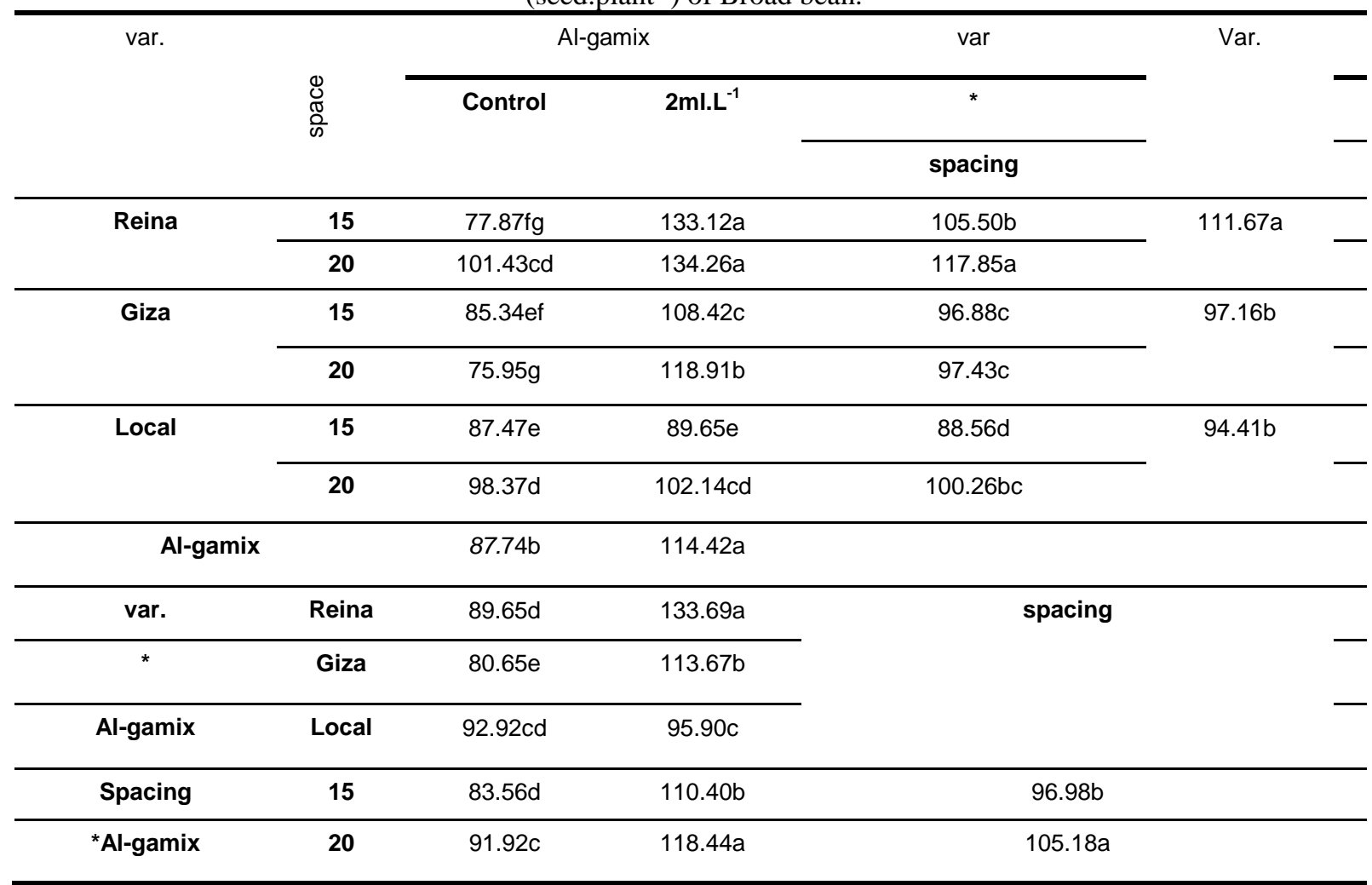

Means within a column, row and there interactions followed with the same letters are not significantly different from each others according to Duncan multiple ranges test at $5 \%$ level.

\section{Seed Weight (g).}

The Data in Table (10), shows that the Reina cultivar significantly overcomes to the other cultivars in weight of seed, which reached $(2.38 \mathrm{~g})$. The two spacing revealed significant differences in weight of seed, the $20 \mathrm{~cm}$ spacing produced higher weight of seed $(2.34 \mathrm{mg})$ compared to $15 \mathrm{~cm}$ $(2.30 \mathrm{~g})$. The foliar Al-gamix concentration significantly affected weight of seed and the highest value $(2.36 \mathrm{~g})$ in $2 \mathrm{ml} . \mathrm{L}^{-1}$ as compared to control treatment $(2.27 \mathrm{~g})$. Significant differences were observed between the cultivars and the spacing in weight of seed, the interaction treatment between Reina cultivar and $20 \mathrm{~cm}$ spacing gave the highest weight of seed which was $(2.48 \mathrm{~g})$ compared to other interaction. The interaction between cultivars and Al-gamix had significantly affect on weight of seed, the interaction treatment betweenReina cultivar and $2 \mathrm{ml} . \mathrm{L}^{-1}$ had the highest weight of seed which was $(2.48 \mathrm{~g})$ and significantly overcame all interaction treatments. Significant differences occurred from the interaction treatments between spacing and Algamix in weight of 100 seed character, the interaction treatment between $20 \mathrm{~cm}$ space and spraying with $2 \mathrm{ml} . \mathrm{L}^{-1}$ gave the highest weight, which was $(2.40 \mathrm{~g})$ compared to other interaction.

The interaction treatments among the three factors indicated to significant differences, spray Reina cultivar with $2 \mathrm{ml} . \mathrm{L}^{-1}$ of Algamix planted in $20 \mathrm{~cm}$ space gave the highest weight $(2.65 \mathrm{~g})$, while the local cultivar planted in $15 \mathrm{~cm}$ spacing and control reatment gave the lowest value $(2.21 \mathrm{~g})$. 
Table (10): Effect of cultivars, plant spacing, Al-gamix and their interaction on seed weight ( $\mathrm{g}$ ) of Broad been.

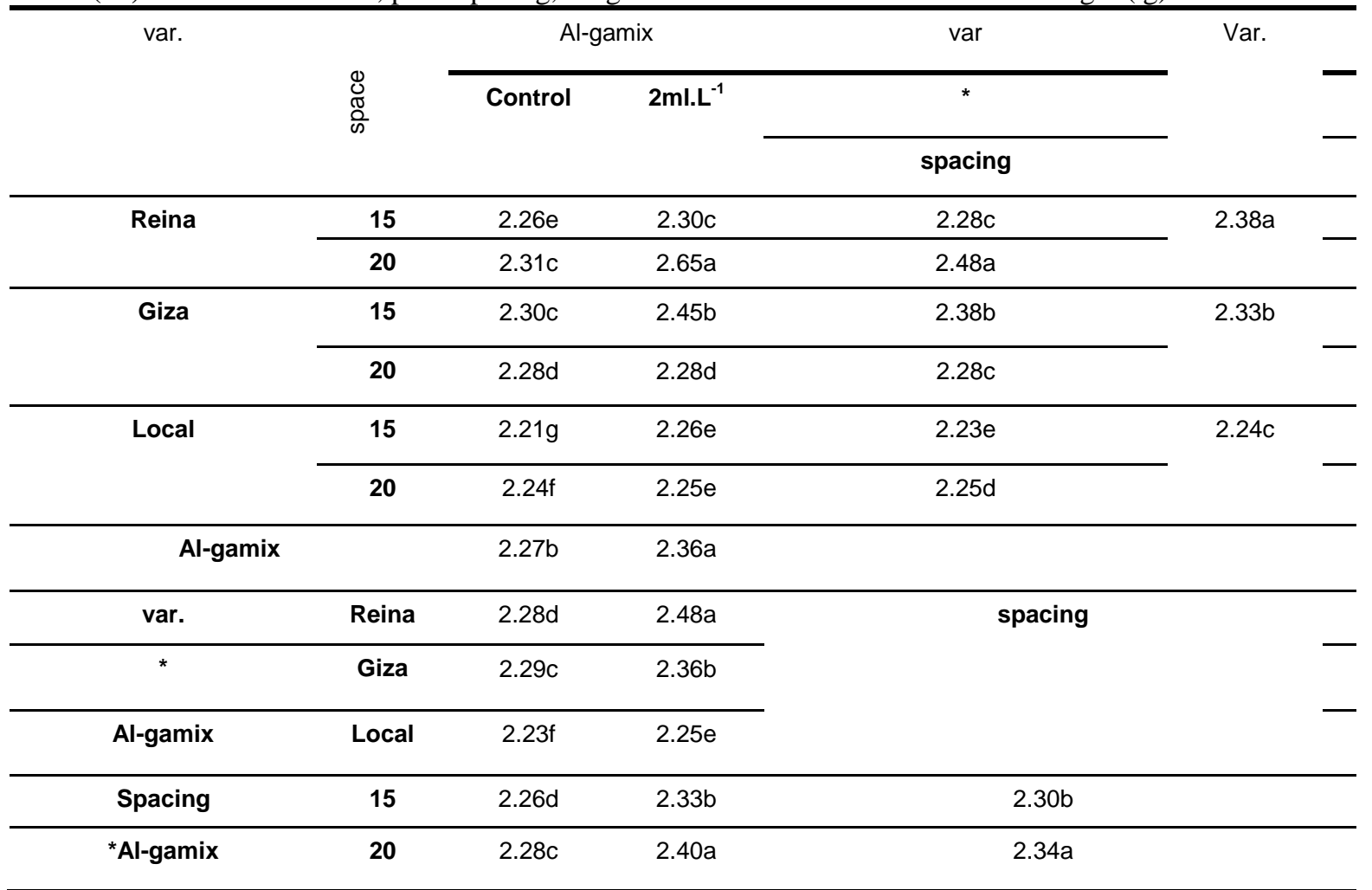

Means within a column, row and there interactions followed with the same letters are not significantly different from each others according to Duncan multiple ranges test at $5 \%$ level.

\section{Weight of 100 Seed (g).}

The results in Table (11), display that the Reina cultivar significantly overcomes on the other cultivar in weight of 100 seed, which reached (237.83) compared to others. The two spacing revealed significant differences in weight of $100 \mathrm{seed}$, the $20 \mathrm{~cm}$ produced higher weight of 100 seed $(233.48 \mathrm{~g})$ compared to $15 \mathrm{~cm}(229.52 \mathrm{~g})$. The foliar Algamix concentration significantly affected weight of 100 seed and the highest value

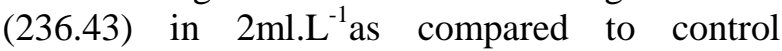
treatment $(226.57 \mathrm{~g})$. Significant differences were observed between the cultivars and the spacing in weight of 100 seed, the interaction treatment between Reina cultivar and $20 \mathrm{~cm}$ gave the highest weight of 100 seed which was $(247.90 \mathrm{~g})$ compared to other interaction. The interaction between cultivars and Al-gamix had significantly affected weight of 100 seed, the interaction treatment between Reina cultivar and $2 \mathrm{ml}^{-\mathrm{L}^{-1}}$ gave the highest weight of 100 seed which was $(247.47 \mathrm{~g})$ and significantly overcame all interaction treatments. Significant differences occurred from the interaction treatments between spacing and Al-gamix in weight of 100 seed character, the interaction treatment between $20 \mathrm{~cm}$ and spraying with $2 \mathrm{ml} . \mathrm{L}^{-1}$ gave the highest weight, which was $(239.47 \mathrm{~g})$ compared to other interaction.

The interaction treatments among the three factors indicated to significant differences among some treatments, spray Reina cultivar with $2 \mathrm{ml} . \mathrm{L}^{-1}$ of Al-gamix planted in $20 \mathrm{~cm}$ spacing gave the highest weight $(265.13 \mathrm{~g})$, while the control treatment in the $15 \mathrm{~cm}$ spacing of local cultivar had the lowest value (221.20g). 
Table (11): Effect of cultivars, plant spacing, Al-gamix and their interaction on weight of 100 seeds $(\mathrm{g})$ of Broad bean.

\begin{tabular}{|c|c|c|c|c|c|}
\hline \multirow[t]{3}{*}{ var. } & \multirow{3}{*}{$\begin{array}{l}0 \\
\mathbb{0} \\
\text { Oे } \\
\text { क }\end{array}$} & \multicolumn{2}{|c|}{ Al-gamix } & var & \multirow[t]{3}{*}{ Var. } \\
\hline & & \multirow[t]{2}{*}{ Control } & \multirow[t]{2}{*}{$2 \mathrm{ml} \cdot \mathrm{L}^{-1}$} & * & \\
\hline & & & & spacing & \\
\hline \multirow[t]{2}{*}{ Reina } & 15 & $225.70 \mathrm{e}$ & $229.80 c$ & $227.75 c$ & $237.83 a$ \\
\hline & 20 & $230.67 c$ & $265.13 a$ & $247.90 a$ & \\
\hline \multirow[t]{2}{*}{ Giza } & 15 & $230.03 c$ & $244.90 b$ & $237.47 \mathrm{~b}$ & $232.60 \mathrm{~b}$ \\
\hline & 20 & $227.57 d$ & $227.90 d$ & $227.73 c$ & \\
\hline \multirow[t]{2}{*}{ Local } & 15 & $221.20 \mathrm{~g}$ & $225.50 \mathrm{e}$ & $223.35 e$ & $224.08 c$ \\
\hline & 20 & $224.27 f$ & $225.37 e$ & $224.82 d$ & \\
\hline \multicolumn{2}{|l|}{ Al-gamix } & $226.57 \mathrm{~b}$ & $236.43 a$ & & \\
\hline var. & Reina & $228.18 d$ & $247.47 a$ & & \\
\hline * & Giza & $228.80 c$ & $236.40 b$ & & \\
\hline Al-gamix & Local & $222.73 f$ & $225.43 e$ & & \\
\hline Spacing & 15 & $225.64 d$ & $233.40 \mathrm{~b}$ & & \\
\hline${ }^{*} A l-g a m i x$ & 20 & $227.50 \mathrm{c}$ & $239.47 a$ & & \\
\hline
\end{tabular}

Means within a column, row and there interactions followed with the same letters are not significantly different from each others according to Duncan multiple ranges test at $5 \%$ level.

\section{Green Seed yield (g.plant ${ }^{-1}$ ).}

It is obvious from Table (12) that there were a significant effect of cultivars on seed yield per plant, Reina cultivar overcome on other cultivars which were (1229.52g.plant $\left.{ }^{-1}\right)$ On the other hand, the effect of spacing had no significantly affected on plant yield. While, Al-gamix concentration significantly affected plant seed yield. The plants which received $2 \mathrm{ml} . \mathrm{L}^{-1}$ had the highest seed yield $\left(1273.63 \mathrm{~g}\right.$ plant $\left.^{-1}\right)$, the lowest yield was $(956.43 \mathrm{~g}$. plant $^{-1}$ ) in control treatments. Significant differences were observed in yield due to cultivars + spacing interaction treatments, the highest yield was recorded for plants from the Reina cultivar with $20 \mathrm{~cm}$ spacing $\left(1405.20 \mathrm{~g}\right.$.plant $\left.{ }^{-1}\right)$. The effect of interaction treatments between the cultivars and
Al-gamix also significantly affected yield, Reina cultivar sprayed with $2 \mathrm{ml} . \mathrm{L}^{-1}$ improved yield and reached $\left(1505.22\right.$ g. plant $\left.^{-1}\right)$ compared to other treatments. Similarly, spacing+ Al-gamix interaction treatments significantly increased seed yield per plant, $20 \mathrm{~cm}$ with $2 \mathrm{ml} . \mathrm{L}^{-1}$ had a highest seed yield $\left(1276.67 \mathrm{~g}\right.$. plant $\left.^{-1}\right)$ as compared to other interaction treatments.

The influence of the interaction consisting of cultivar + acids + concentration had a significant effect on the seed yield per plant and the maximum yield was for plants from Reina cultivar that were sprayed with $2 \mathrm{ml} . \mathrm{L}^{-1}$ of Al-gamix planted in $20 \mathrm{~cm}$ (1734.44.plant ${ }^{-1}$ ), while the minimum yield was in the Rina cultivar $+15 \mathrm{~cm}+$ control treatment (831.70g.plant $\left.{ }^{-1}\right)$.

Table (12): Effect of cultivars, plant spacing, Al-gamix and their interaction on Seed yield (g.plant ${ }^{-1}$ ) of Broad bean.

\begin{tabular}{|c|c|c|c|c|c|}
\hline \multirow[t]{2}{*}{ var. } & \multirow{2}{*}{$\begin{array}{l}\mathbb{D} \\
\mathbb{J} \\
\mathbb{O}\end{array}$} & \multicolumn{2}{|c|}{ Al-gamix } & \multirow{2}{*}{$\frac{\text { var }}{\text { * }}$} & \multirow[t]{2}{*}{ Var. } \\
\hline & & Control & $2 \mathrm{ml} \mathrm{L}^{-1}$ & & \\
\hline
\end{tabular}




\begin{tabular}{|c|c|c|c|c|c|}
\hline \multirow{3}{*}{ Reina } & \multirow{3}{*}{$\frac{15}{20}$} & \multirow{3}{*}{$\frac{831.70 f}{1075.95 d}$} & \multicolumn{3}{|c|}{ disance } \\
\hline & & & $1276.00 \mathrm{c}$ & $1053.85 \mathrm{c}$ & $1229.52 a$ \\
\hline & & & $1734.44 a$ & $1405.20 \mathrm{a}$ & \\
\hline \multirow[t]{2}{*}{ Giza } & 15 & 988.47de & $1539.78 b$ & $1264.13 b$ & $1148.82 b$ \\
\hline & 20 & $984.35 \mathrm{de}$ & $1082.66 d$ & $1033.51 \mathrm{~cd}$ & \\
\hline \multirow[t]{2}{*}{ Local } & 15 & 934.96ef & 995.94de & $965.45 d$ & $966.74 c$ \\
\hline & 20 & 923.13ef & $1012.92 \mathrm{de}$ & $968.03 d$ & \\
\hline \multicolumn{2}{|c|}{ Al-gamix } & $956.43 b$ & $1273.63 a$ & & \\
\hline var. & Reina & $953.83 c$ & $1505.22 \mathrm{a}$ & \multicolumn{2}{|c|}{ Distance } \\
\hline * & Giza & $986.41 \mathrm{c}$ & $1311.22 b$ & & \\
\hline Al-gamix & Local & $929.05 c$ & $1004.43 c$ & & \\
\hline spacing & 15 & $918.38 c$ & $1270.58 a$ & & \\
\hline${ }^{*} \mathrm{Al}$-gamix & 20 & $994.48 b$ & $1276.67 a$ & & \\
\hline
\end{tabular}

Means within a column, row and there interactions followed with the same letters are not significantly different from each others according to Duncan multiple ranges test at $5 \%$ level.

\section{Total Seed Yield (ton. donum ${ }^{-1}$ ).}

Table (13) displays that there were a significant differences between cultivars in the total seed yield, the Reina cultivar overcome to other cultivars which valued (7.73 ton.donum ${ }^{-1}$ ). The two spacing in total yield were accessed to no significant level, Spraying the plants with Algamix significantly increased the total seed yield; $2 \mathrm{ml} . \mathrm{L}^{-1}$ resulted in a higher total yield (8.01 ton.duonum ${ }^{-1}$ ) as compared to a lower value from control treatment which was $\left(6.01\right.$ ton.donum $\left.^{-1}\right)$. The interaction treatment between cultivars and spacing significantly affected total seed yield, the interaction between Reina cultivars and $20 \mathrm{~cm}$ gave higher total yield reached (8.83ton.donum ${ }^{-1}$ ) as compared to other interaction. The interaction effect between cultivars and Al-gamix also had significant effect the highest value (9.46ton.donum ${ }^{-1}$ ) recorded between Reina cultivars and $2 \mathrm{ml} . \mathrm{L}^{-1}$. compared to other interaction. The interaction between spacing and Al-gamix revealed significant effect on total green seed yield, the higher interaction (8.03ton.donum ${ }^{1}$ ) between $20 \mathrm{~cm}$ spacing and $2 \mathrm{ml} . \mathrm{L}^{-1}$ compared to other interaction.

The interaction effect among three factors had also significant effect on total seed yield, the higher value (10.90 ton.donum $\left.{ }^{-1}\right)$ was observed in interaction among Reina cultivar sprayed with 2. $\mathrm{ml} . \mathrm{L}^{-1}$ Algamix planted in $20 \mathrm{~cm}$ spacing, while the lowest value (5.23 ton.donum ${ }^{-1}$ ) among Reina cultivars, $15 \mathrm{~cm}$ spacing and control treatment.

Table (13): Effect of cultivars, plant spacing,Al-gamix and their interaction on total green seeds yield(ton.donum ${ }^{-1}$ ). var.

Al-gamix

var

Var.

\begin{tabular}{|c|c|c|c|c|c|}
\hline & \multirow{2}{*}{ 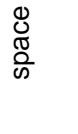 } & \multirow[t]{2}{*}{ Control } & \multirow[t]{2}{*}{$2 \mathrm{ml} \cdot \mathrm{L}^{-1}$} & * & \\
\hline & & & & spacing & \\
\hline \multirow[t]{2}{*}{ Reina } & 15 & $5.23 f$ & $8.02 \mathrm{c}$ & $6.624 c$ & $7.73 a$ \\
\hline & 20 & $6.76 \mathrm{~d}$ & $10.90 a$ & $8.833 a$ & \\
\hline \multirow[t]{2}{*}{ Giza } & 15 & $6.21 \mathrm{ef}$ & $9.68 \mathrm{~b}$ & $7.946 b$ & $7.22 b$ \\
\hline & 20 & $6.19 \mathrm{de}$ & $6.81 d$ & $6.496 \mathrm{~cd}$ & \\
\hline
\end{tabular}




\begin{tabular}{cccccc}
\hline Local & $\mathbf{1 5}$ & $5.88 \mathrm{ef}$ & $6.26 \mathrm{de}$ & $6.069 \mathrm{~d}$ & $6.08 \mathrm{c}$ \\
\cline { 2 - 5 } & $\mathbf{2 0}$ & $5.80 \mathrm{ef}$ & $6.37 \mathrm{de}$ & $6.085 \mathrm{~d}$ & \\
\hline Al-gamix & & $6.01 \mathrm{~b}$ & $8.01 \mathrm{a}$ & & \\
\hline var. & Reina & $6.10 \mathrm{c}$ & $9.46 \mathrm{a}$ & Spacing & \\
\hline$*$ & Giza & $6.20 \mathrm{c}$ & $8.24 \mathrm{~b}$ & & - \\
\hline Al-gamix & Local & $5.84 \mathrm{c}$ & $6.31 \mathrm{c}$ & & \\
\hline spacing & $\mathbf{1 5}$ & $5.77 \mathrm{c}$ & $7.99 \mathrm{a}$ & $6.88 \mathrm{a}$ & $7.14 \mathrm{a}$
\end{tabular}

Means within a column, row and there interactions followed with the same letters are not significantly different from each others according to Duncan multiple ranges test at $5 \%$ leve.

\section{DISSCUTION}

It is evident from the previously mentioned results in table $(2,6,7,8,9,10,11,12$ and 13$)$ the Reina cultivar superior to the Giza and Local cultivar in (No. of branch per plant, Pod Yield g. plant $^{-1}$, Total Yield ton. donum ${ }^{-1}$, No. of seed per pod, No. of seed. Plant ${ }^{-1}$, seed weight g, weight of 100 seed g, seed yield.plant ${ }^{-1}$ and Total seed yield ton. Donum ${ }^{-1}$ ), while Giza cultivar superior to other cultivars in (plant length $\mathrm{cm}$, pod length $\mathrm{cm}$, pod weight $\mathrm{g}$ ) which is due to the genotype differences among the three cultivars and the increase in absorption of the nutrient in the soil, may be due to the differences in root system and RCEC (Root Cation Exchange Capacity) which is differing among cultivars. These results are in harmony with those of the(Bakry et al., 2011; Osman et al., 2010), and also the differences between studied cultivars in growth habit and response of each one to environmental conditions during the growing season which are controlled by genetically factors. That may be reflected on the nodulation and $\mathrm{N}$-fixation consequently growth characteristics. Similar results were obtained by ( El-Masry, 2010; Derya, 2013 and Kuber et al., 2016).

These results provide clear evidence that the 15 plants spacing will increase plant growth, which may be lead that the plants taking sufficient nutrients and water in addition to the light with less competition between plants for nutrients, water and light. The reduction of leaf chlorophyll content could be explained partially by the effects of shading of the lower canopy, causing poor canopy interception of the photo synthetically active radiation (Brahim et al., 1998).
Significantly differences occurred between plant spacing in green and seed yield characters. $15 \mathrm{~cm}$ spacing increased (plant high $\mathrm{cm}$, No. of branches, pod weight g, plant yield g. plant ${ }^{-1}$, total yield ton.donum $\left.{ }^{-1}\right)$. But $20 \mathrm{~cm}$ spacing significant increased (No. of pods per plant, pod length $\mathrm{cm}$, No. of seed per pod, seed weight g, weight of 100 seed g). This may be attributed to the over shadowing of the plant due to the highest number of plants per unit area. That yield per donum increased with higher planting densities was probably due to an increase in the number of plants per unit area, which might have contributed to the production of extra yield per unit area leading to high yield high plant density can cause lodging, less light penetration in the crop canopy, reduced photosynthetic efficiency and can reduce the yield drastically (Vassilev, 1998; Jettner et al., 1998a 1998b; Lemerle et al., 2004; Lemerle et al., 2006). Earlier studies have shown that yield and its components are affected by planting densities (Turk \& Tawaha, 2002; Bakry et al., 2011; Thalji, 2006 \& 2010; Khalil et al., 2011). The closer spacing (high planting density) might have enabled maximized the use of the applied nutrients better than the wider spacing (low planting density).

Spraying broad bean plants with Al-gamix significant affected on the growth and green yield of pods and seed characteristics, In general, seaweed extracts contain important growth hormones like Auxin, gibberellins and Cytokinin which induce cell division, increase cell enlargement, lead to balance of the physiological and biological processes, increase photosynthesis processes and improve growth characters (Jensen, 2004). The positive effect of seaweed extracts on 
the vegetative growth characters table (1\&2) may be due to the mineral content $\mathrm{Zn}, \mathrm{Cu}$ and $\mathrm{B}$ in the seaweed extracts which promote cell division and enlargement and induce the photosynthesis leading to better vegetative growth. It might also be due to the macronutrient that the seaweed extracts contain like $\mathrm{N}, \mathrm{P}, \mathrm{K}$, which (macronutrients) play a great role in plant nutrition which are essential for the growth of plant (Lopes et al., 2008 and Attamimy, 2009). The beneficial effect of seaweed extracts on crop yield table (3, $4,5,6,7,8,9,10,11,12$ and 13) could be due to the stimulatory influence of seaweed concentration on triggering early flowering and fruit set (Arthur et al., 2003). The micronutrients status of the soil is limited. Low rates of nutrients will not be sufficient to close the gap between crop need and supply. The continuous use of low rates of fertilizer nutrients can deplete the soil nutrient reserves, so the uses of seaweed provide the plants with mineral elements and stimulating the action of soil bacteria. The present investigation demonstrated that faba bean root criteria increased with foliar spray with seaweed extract, whereas shoot parameters were enhanced with foliar spray. Pigment content of faba bean was also increased on foliar spray, these results were in favor with the findings of Blunden $\boldsymbol{e t}$ al. (1996) and Crouch and van Staden (2005) also found that the seaweed concentrate stimulated root growth at the expense of shoot growth and increase of the overall photosynthetic accumulation efficiency of the plant. A better root system might be attributed to endogenous auxin and related compounds in the extracts. Yield enhancement in plants treated with seaweed extracts is thought to be associated with the hormonal substances existing in the extracts, particularly cytokinins. This was evident in fruits treated with seaweed extracts which had higher cytokinin levels as compared with untreated fruits (Featonby and Van Stadena, 1983). In addition to growth hormones, the increase in yield characters could be due to the fact that seaweed extracts contain macro and micronutrients and organic matters like amino acids that improve nutritional status, vegetative growth and yield quality (O'Dell, 2003). These results are in harmony with the findings by Gajewski et al. (2008) on Chinese Cabbage, Allelah (2011) on melon.

\section{CONCLUSION}

The obtained results revealed that the Reina cultivar superior over the Giza and Local cultivars in more character. Plant spacing $15 \mathrm{~cm}$ enhance vegetative and some yield characters, while $20 \mathrm{~cm}$ spacing increase other yield characters. Foliar spraying faba bean plants with Al-gamix was beneficial to the crop growth and yield along with vegetative, green pods and seeds. Hence, it could be suggested that the Reina cultivar is suitable with area condition and faba bean grown under the experiment and similar growing conditions and foliar sprayed with Al-gamix to produce high quantity and good quality of some characters green pods, green yield and green seed yield suitable for marketing.

\section{REFERENCES.}

- Allelah, W.B.M. (2011). Effect of urea fertilization and seaweed extracts (Algamix and Algreen) on the shoot growth and total yield of melon. Journal of Tikrit Univ. for agricultural sciences. 11(1): 136-142. (In Arabic).

- AL-Rawi, Kh.M. and A.A.M. Khalaf Alah (2000). Design and analysis of Agricultural experiments. Musol Univ. Ministry of Higher Education and Scientific Research. Iraq. (In Arabic)

- Anonymous. (2010). http://faostat.fao.org/site/339/default.aspx.

- Attamimy, J.Y.A. (2009). The effect of humic acid and seaweed extracts on the growth, chemical characteristics Rosmarinus officinalis L. the 6th scientific conference, Biology dept., College of Education, University of Tikrit. Plant Scie. P:117.

- Bakry, B.A., T.A. Elewa, M.F. El-Karamany, M.S. Zeidan and M.M. Tawfik. (2011). .Effect of row spacing on yield and its components of some faba bean varieties under newly reclaimed sand soil condition. World J. of Agri. Sci., 7(1): 6872.

- Blunden, G.; T. Tenkins and Y.W. Liu (1996). Enhanced leaf chlorophyll levels in plants treated with seaweed extract. Journal of Applied Phycology, 8(6): 535-543.

- Brahim, K.; D.T. Ray and D.A. Dierig (1998). Growth and yield characteristics of (Lesquerella fendleri) as a function of plant density. Ind. Crops prod., 9: 63-71.

- Crouch, I.J. and J. Vanstaden (2005). Effect of seaweed concentrate on the establishment and yield of green house tomato plant. Jour. of Applied Phycology. 4(4): 291-296.

- Derya O.Y. (2013).Optimal Intra-Row Spacing For Production Of Local Faba Bean (Vicia faba L. 
MAJOR) Cultivars in the Mediterranean Conditions. Pak. J. Bot., 45(6): 1933-1938.

- EL-masry, M.F., (2010). Effect of some cultural practices of faba bean (Vicia faba L.). MSc. Thesis, Fac. of Agric., Alex. Univ., Egypt.

- en los animales tras la ingestión de semillas de Vicia faba. Rev. Esp. Fisiol., 38: 345-351.

- Featonby. S. , B. C. and J. Van Stadena (1983). The effect of sea weed concentrate on the growth of tomato plants in nematode - infested soil. Scientia Horticulture, 20(2): 137-146.

- Gajewski, M.; G. Katarzyna and J. Bobruk (2008). The influence of Goëmar Goteo bio stimulator on yield and quality of two Chinese cabbage cultivars. Conf. of bio stimulators in modern agriculture "vgetable crops". Warsaw pp 23-27.

- Ismael, S.F. (2012). Effect of temperature and sea weeds extracts on growth and yield of two cucumber cultivars (Cucumis sativus L.). M.Sc thesis, College of Agriculture, University of Duhok, Kurdistan, Iraq.

- Jensen ,E.(2004). Seaweed Fact or Fancy. From the organic broadcaster, published by moses the Midwest organic and sustainable education. From the broadcaster. Vol.12(3):164-170 .

- Jettner, R., S.P. Loss, K.H.M. Siddique and L.D. Martin. (1998a.) Response of faba bean to sowing rates in south-western Australia. i. seed yield and economic optimum plant density. Australian J. Agri. Res., 49: 989-998.

- Jettner, R., S.P. Loss, K.H.M. Siddique and L.D. Martin. (1998b.) Response of faba bean to sowing rates in South-Western Australia II. Canopy development radiation absorption and dry matter partitioning. Australian J. Agri. Res., 49: 999-1008.

- Khalil, S.K., A.W. Amanullah and A.Z. Khan. (2011). Variation in leaf traits, yield and yield components of faba bean in response to planting dates and densities. Egypt Acad. J. Biolog. Sci., 2(1): 35-43.

- Kuber, T.E.; C.V.Raghavaiah \& I. Hamza. (2016). Production Potential of Faba Bean (Vicia faba L.) Genotypes in Relation to Plant Densities and Phosphorus Nutrition on Vertisols of Central Highlands of West Showa Zone, Ethiopia, East Africa. Adv Crop Sci Tech 4: 214. doi:10.4172/2329-8863.1000214.

- Lemerle, D., B. Verbeek and S. Diffey. (2006). Influence of field pea (Pisum sativum) density on grain yield and competitiveness with annual rye grass (Lolim rigidum) in South-Eastern Australia. Australian J. Exp. Agri., 46: 14651472.

- Lemerle, D., R.D. Causens, L.S. Gill, S.J. Peltzer, M. Moerkerk, C.E. Murphy, D. Collins and B.R.
Cullis. (2004). Reliability of higher seeding rates of wheat for increased competitiveness with weeds in low rainfall environment. J. Agric. Sci., 142: 395-409.

- Lopes, R.; F. Cabrera; E. Madejan; F. Sancho and M. Alvares (2008). Urban compost as an Alternative for peat in Forestry Nursery growing media. Dynamic soil. Dynamic plant. 1 (1 special Issue): 60-66.

- O'Dell ,C.(2003). Natural Plant Hormons are Biostimulates Helping Plant Develop High Plant Antioxidant Activity For Multiple Benefits. Virginia Vegetable Small Fruit and specialty Crops Nov.-Des. ,2(6):1-3 .

- Osman, A.A.M.; S.O.Yagoub\& O.A.Tut. (2010). Performance of faba beans (Vicia faba L.) cultivars grown in new agroecological region of Sudan (Southern Sudan ). Aust. J. of Basic. and Appl. Sci., 4(11): 5516-5521.

- Potter ,G. (2005). www.kaizenbonsai.com

- Sabh , A.Z. and M.A Shallan (2008). Effect of organic Fertilization of Broad Bean ( Vicia Faba L.) By using different Marine Macroalgae in Relation to the Morphological Characteristics and Chemical Constituents of the plant . Aust . J. Basic and Appl . Sci . , 2(4 ) : 1076-1091.

- Sarah, A., E. Abusin, A.B. Hassan and E.E. Babiker.(2009). Nutritional evaluation of cooked faba bean (Vicia Faba L.) and white bean (Phaseolus Vulgaris L.) cultivars. Australian J. of Bas. and App. Sci., 3(3): 24842490.

- Thalji, T. (2006). Impact of row spacing on faba bean growth under Mediterranean rainfed conditions. J. of Agro., 5(3): 527-532.

- Thalji, T. (2010). Effect of plant density on seed yield and agronomic characters of faba bean (Vicia faba L.) under greenhouse conditions. Bios. Res., 7(1): 22-25.

- Turk, M.A. and A.R.M. Tawaha. (2002). Impact of seeding rate, sedding date, rate and method of phosphorus application in faba bean (Vicia faba L. Minpr) in the absence of moisture stres. Biotechnol. Argon. Soc. Environ., 6(3): 171178.

- Vassilev, V.I. (1998). Pseudomonas Marginalis pv. Marginalis and some other bacteria on faba bean. FABIS Newsletter 41: 21-24.

- Zodape, S.T.; Abha Gupta; S.C. Bhandari; U.S. Rawat; D.R. Chaudhary; K. Eswaran and J. Chikara (2011). Foliar application of seaweed sap as bio stimulant for enhancement of yield and quality of tomato. Journal of Scientific and Industrial Research Vol. (70):pp. 215-219. 


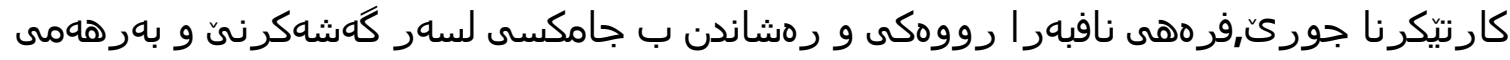
سووزى ينى باقلكن (

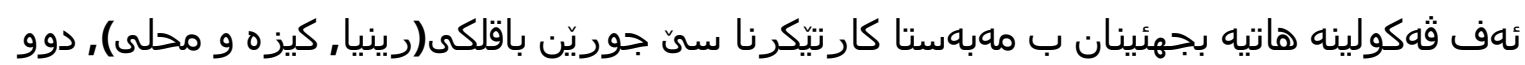

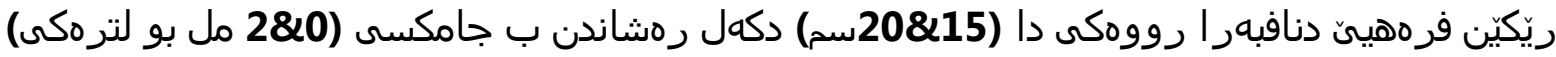

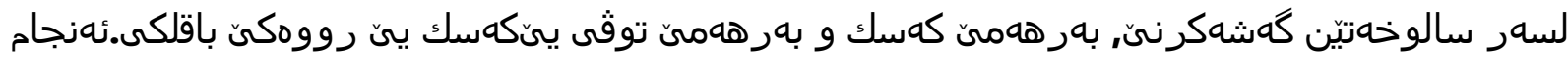

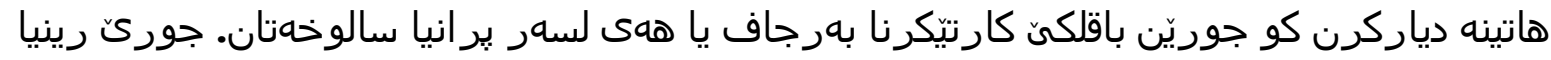

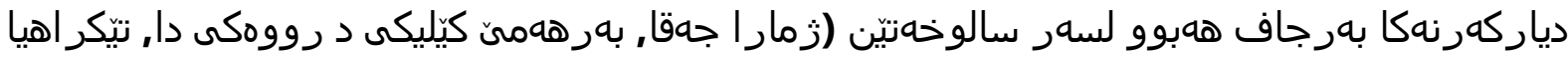

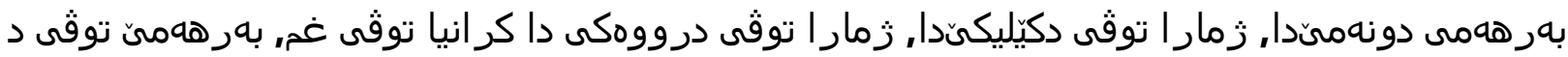

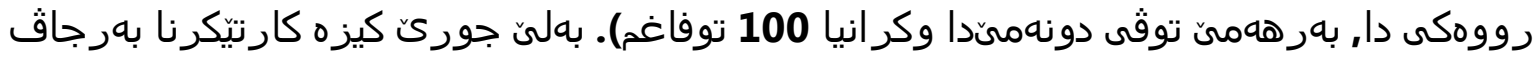

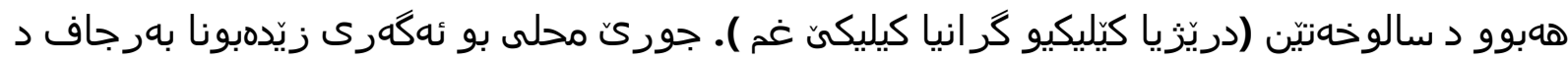

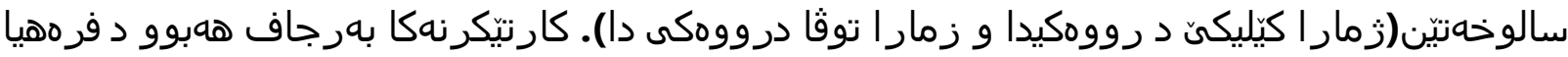

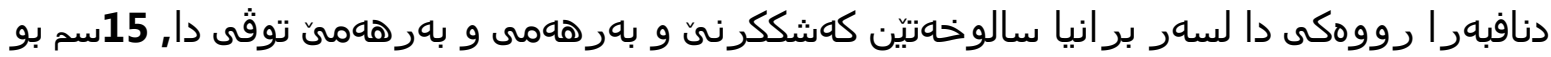

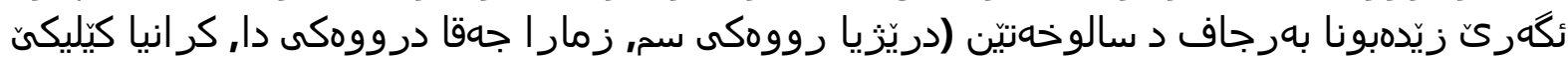

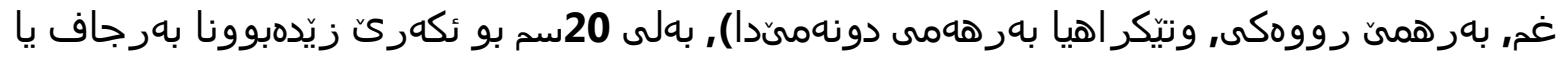

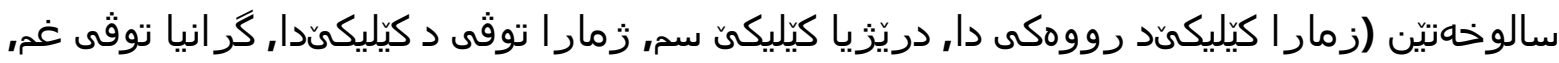

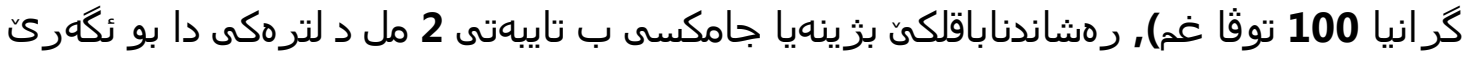

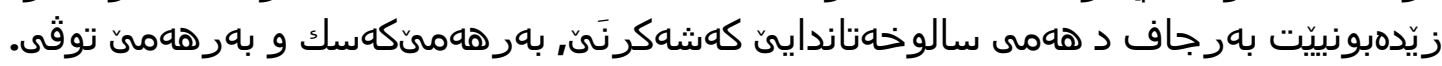

